\title{
Biomass-Based Innovations in Demand Driven Research and Development Projects in Africa
}

\author{
Jatta Raymond ${ }^{1}$, Kwapong Nana Afranaa ${ }^{1,2, *}$, Nero Bertrand Festus ${ }^{1,3}$ and Fatunbi Oluwole ${ }^{1}$ \\ 1 Directorate of Research and Innovation, Forum for Agricultural Research in Africa (FARA), \\ 12 Anmeda Street, Roman Ridge, PMB CT 173 Accra, Ghana; rjatta@faraafrica.org (J.R.); \\ bnero@faraafrica.org (N.B.F.); ofatunbi@faraafrica.org (F.O.) \\ 2 Department of Agricultural Extension, University of Ghana, P.O. Box LG 68, Legon, \\ GA-492-3175 Accra, Ghana \\ 3 Department of Land Reclamation and Rehabilitation, Kwame Nkrumah University of Science and \\ Technology, AK-448-4835 Kumasi, Ghana \\ * Correspondence: nkwapong@ug.edu.gh or nkwapong@faraafrica.org
}

Received: 28 May 2018; Accepted: 11 July 2018; Published: 27 July 2018

\begin{abstract}
The case for demand-driven research and development has received important considerations among governments, donors and programme implementing partners in development planning and implementation. Addressing demand is believed to be a bottom-top approach for designing and responding to development priorities and is good for achieving development outcomes. In this paper, we discuss the concept and application of demand-driven research and development (DDRD) in Africa. We use evidence of six projects implemented under the BiomassWeb Project in Africa. We focus on parameters on level of engagement of stakeholders—whose demand is being articulated, the processes for demand articulation, capacity building and implementation processes, innovativeness of the project, reporting and sustainability of the project. We find that the nature of the institutions involved in articulation and implementation of demand-driven research and development projects and their partnerships influence the impact and reporting of demand-driven projects.
\end{abstract}

Keywords: demand-driven research; Biomass; innovation; Ghana

\section{Introduction}

There is an increasing recognition of the challenge that African agriculture faces to grow more food to feed its fast growing and urbanizing population in situations of greater uncertainty because of impact of climate change and growing instability associated with land, water and energy shortages. Today, productivity (i.e., cereal yields) is estimated at 1.6 tons/ha in Africa, compared to 6.6 tons/ha in Europe and 3.9 tons / ha globally. The imperative is to deepen the application of science, technology and innovation in all agricultural processes [1]. The ability of science to lead to agricultural transformation depends to a considerable extent on what science is to be applied and for which constituency. This has a bearing on the use of research evidence, policy action, adoption rates as well as sustainable of project and programme outcomes. This brings to the fore the concept and application of demand-driven research and development (DDRD). The argument of demand- driven research is based on a realization that when research is close to the needs of the end users, it can easily be adapted, adopted and used [2]. Demand-driven and locally-driven national agricultural research systems are believed to support better overall institutional capacities, linkages among partners in the sector as well as sustainability of outcomes.

However, the inadequate funding for research often means that donors are the main drivers of research in Africa. Service delivery therefore remains largely supply-driven and organizations fail 
to effectively contribute to the real goal of providing more efficient and effective quality services for farmers to enhance rural development. These arguments are also similar to that of demand-driven development programmes promoted by donor and development partners. For example, World Bank's lending to demand-driven projects was estimated to rise from $\$ 325$ million in 1996 to $\$ 2$ billion in 2003 [2]. Demand-driven interventions are regarded as a mechanism for enhancing sustainability, making development more inclusive and empowering end users. However, demand-driven intervention in some areas also suffer from challenges of elite capture, misapplication of funds, low capacity etc. These issues are applicable to research funding much as they are to mainstream development interventions. This study is significant to the extent that it shows that the processes for demand articulation, the stakeholders involved in the process (articulation and implementation) and their linkages to end users are important in ensuring impact and sustainability of the project outcomes.

In 2016, the Forum for Agricultural Research in Africa (FARA) and the Centre for Development Research (ZEF), University of Bonn initiated demand-driven research and development under the BiomassWeb Project. The demand-driven research was to provide an opportunity for partner organizations within the BiomassWeb project to carry out further research and development activities to reinforce the possible outcomes of on-going BiomassWeb activities, and in addition to use the knowledge gained to improve the livelihoods of the people. The DDRD activities aimed to increase stakeholders' participation and contribute to research and development activities of BiomassWeb project. The DDRD activities must be driven by need or demand from potential beneficiaries. Grants were provided to successful partner organizations. On the basis of evidence on demand, innovativeness, ease of adoption and potential impact, Forum for agricultural research in Africa (FARA) and Center for Development Research (ZEF), University of Bonn shortlisted thirteen projects. The thirteen shortlisted projects were then submitted to external evaluators for their review. Following the external evaluators' review and recommendations, six proposals were selected for funding (see Table 1). Using evidence on the emerging results of six projects implemented in Ethiopia, Ghana and Nigeria, this paper examines the following questions.

1. Are demand driven projects easily adoptable or upscaled?

2. Does the implementation of demand-driven projects necessarily ensure the higher impact and sustainability of outcomes?

Table 1. Selected demand-driven research for development (DDRD) sub projects under the Biomassweb project.

\begin{tabular}{|c|c|c|c|}
\hline Applicant Affiliation & Title of the Project & Country & Crop \\
\hline $\begin{array}{l}\text { Ministry of Food and Agriculture, } \\
\text { Accra, Ghana }\end{array}$ & Using cassava peels for mushroom cultivation & Ghana & cassava \\
\hline $\begin{array}{l}\text { Council for Scientific and } \\
\text { Industrial Research (CSIR) Food } \\
\text { Research Institute, Accra, Ghana }\end{array}$ & $\begin{array}{l}\text { Developing biomass-based value chain of plantain } \\
\text { and reduce post-harvest losses of plantain through } \\
\text { the development of value added products for small } \\
\text { scale farmers and processors in two regions in Ghana }\end{array}$ & Ghana & plantain \\
\hline $\begin{array}{l}\text { International Network for Bamboo } \\
\text { and Rattan, Kumasi, Ghana }\end{array}$ & $\begin{array}{l}\text { Exploring the potential of bamboo leave fodder for } \\
\text { livestock production in Ghana }\end{array}$ & Ghana & bamboo \\
\hline $\begin{array}{l}\text { Department of Agricultural and } \\
\text { Environmental Engineering, } \\
\text { University of Ibadan, Nigeria }\end{array}$ & $\begin{array}{l}\text { Production of bio-plastics and bio-gels from } \\
\text { agricultural waste to promote their } \\
\text { biomassweb values }\end{array}$ & Nigeria & cassava, maize, banana \\
\hline $\begin{array}{l}\text { Department of Agricultural and } \\
\text { Environmental Engineering, } \\
\text { Federal University of Technology, } \\
\text { Akure, Ondo State, Nigeria }\end{array}$ & $\begin{array}{l}\text { Mass and energy balance analysis of pneumatic } \\
\text { dryers for cassava and development of optimization } \\
\text { models to increase competitiveness }\end{array}$ & Nigeria & cassava \\
\hline $\begin{array}{l}\text { YOM Institute of Economic } \\
\text { Development, Ethiopia }\end{array}$ & $\begin{array}{l}\text { Exploring potentials of the bamboo sector for } \\
\text { employment and food security in Ethiopia: An } \\
\text { institutional analysis of bamboo-based valueweb }\end{array}$ & Ethiopia & bamboo \\
\hline
\end{tabular}




\section{Materials and Methods}

To answer the questions indicated above, our analysis is guided by the "FARA bio-economy innovation-to-impact framework" for developing, testing and refining models for generation, uptake, out-scaling and commercialisation of innovations [3]. The key selling point is about ensuring technology adoption for increased livelihood outcomes through the use of multi-stakeholder innovation platforms for articulation of demand-driven research and for technology development and outreach.

We review the DDRDs based on FARA's Innovation to Impact model framework described below (Figure 1). To operationslize the model our framework is built on three key parameters:

- Partner engagement in project design

- Quality of the research results/outputs

- Sustainability of project outcomes

The use of these parameters allowed us to assess the quality of the deliverables and engagement of partners at each of the project processes from identification of the project activities to communication of research outputs. Under partner engagement, we consider the type of partner e.g., research institutions, NGOs' and the kind of partnership arrangement and funding mechanism. Also, who or which institution is demanding the research and whose demand is the project responding to. This included the research needs, community needs, industry needs, environmental needs, etc. The process of implementation and the level of participation of different stakeholders especially women is also assessed.

The DDRD projects are evaluated based on the demand for the project to address specific socio-economic and environmental challenges through the innovative use of biomass to generate and develop bio-based services and products. The results of the DDRD projects are to be easily up-scaled, adapted, adopted and used. Communication of research output/outcomes and capacity building of actors is considered key to ensure adoption, upscaling and sustainability.

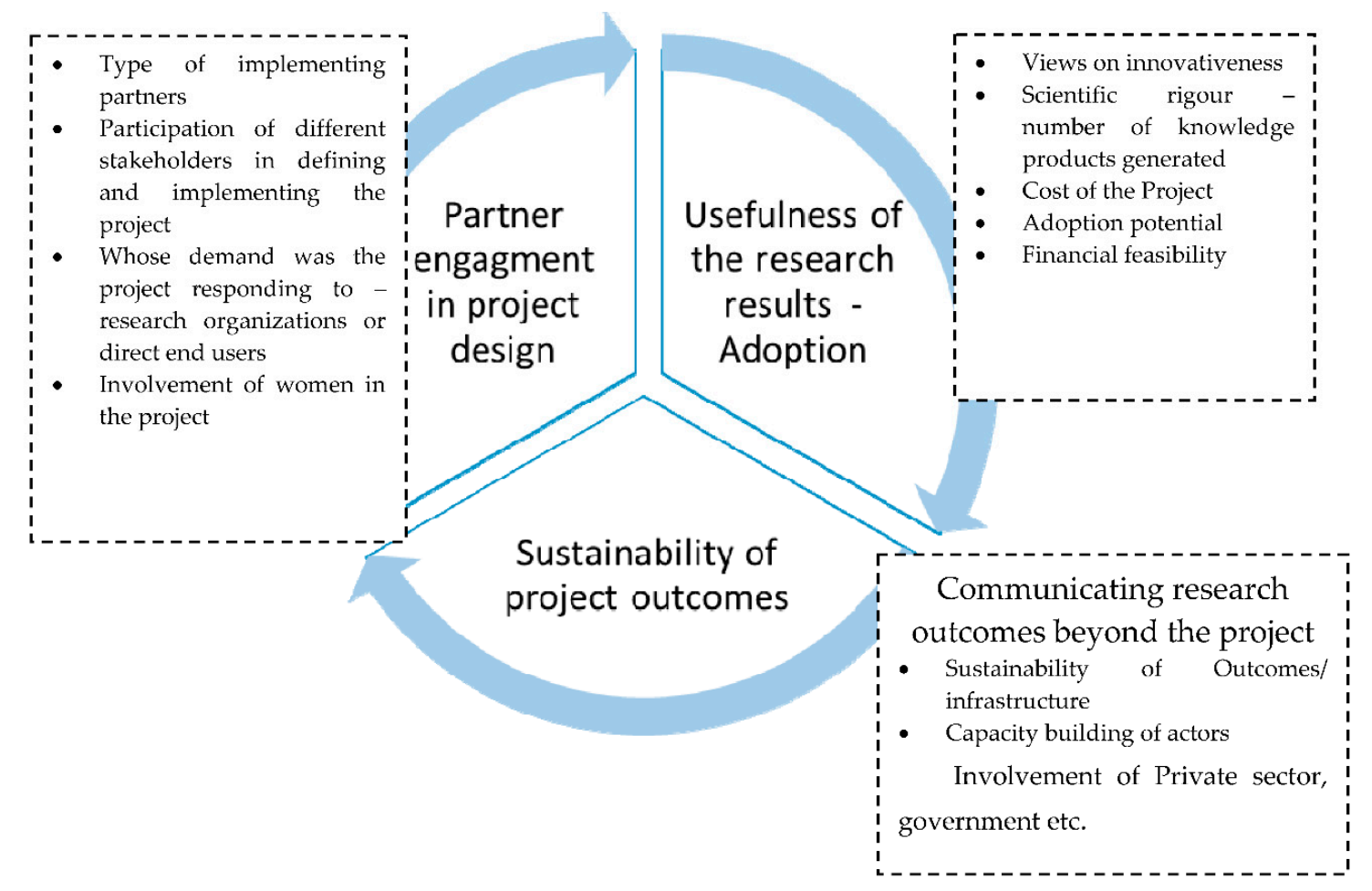

Figure 1. Analytical Framework. 
For this study, we use qualitative methodology for the data collection and analysis. Project documents and reports on six implemented DDRD projects (Table 1) were reviewed and content analyzed. We focused on the parameters described in the conceptual framework. This included the partner engagement, demand for project, project goal, implementation process, innovativeness of the project, sustainability and scalability of project, project end-users, capacity building, delivery and adoption of innovative technologies. Focus group discussions and personal interviews were conducted with some of the project beneficiaries. Also key informant interviews were conducted with project managers and principal researchers of the BiomassWeb DDRD projects. BiomassWeb stands for improving food security in Africa through increased systems productivity of biomass-based value webs. BiomassWeb aims at improving the availability of and access to food (food security) in Sub-Saharan Africa through producing, processing and trading of biomass in biomass-based value webs. Biomass-based value webs are complex systems of interlinked value chains in which food and non-food biomass is produced, processed, traded and consumed.

\section{Results}

The following section provides information on the innovation processes in each of the six projects (Table 1) and the relation between end-users and researchers in the generation and adoption of new technologies in innovative use of cassava biomass for the production of mushroom, addressing postharvest losses of plantain, use of bamboo biomass for feeding livestock, production of bio-plastics and bio-gels from agricultural waste, improved engineering design of pneumatic flash dryers to regulate heat loss and improve on the quality of high quality cassava flour produced, and lastly exploring the potential of the bamboo sector for employment and food security. Discussions are centred on BiomassWeb DDRD project planning, innovations in the use of biomass, capacity building/demonstrations, delivery and adoption of innovative technologies.

\subsection{Using Cassava Peels for Mushroom Production, Ghana}

\subsubsection{Demand Driven Research Planning}

The goal of the project was to use cassava peel waste which is generated in the production of Gari/cassava chips, as substrate for the production of mushroom to generate income, improve household nutrition security and minimize environmental degradation. Three major actors were involved in this demand-driven research and development (DDRD) project. The funder-Forum for Agricultural Research in Africa (FARA/BiomassWeb project) and Centre for Development Research (ZEF), the facilitators/implementers (Women in Agricultural Development), and the beneficiaries (extension agents, and farm families of Gomoa). A key observation to note in this DDRD is the fact that the innovation was generated by the researchers (or facilitators/implementers) and supplied or transferred to the local community with funding from the development partner. In this case the donor agency (FARA/ZEF) demands the knowledge and innovation on behalf of the end-users and goes a step further to demand the empowerment of these end-users. Local farm families and the youth of Gomoa were trained on cassava peel composting, bagging the substrates, inoculating the substrate with spores, daily culture of the inoculated substrate/growing mushrooms, harvesting the matured mushrooms, drying and packaging for the market, as well as the marketing of either the mushrooms or the substrate. A mushroom house was constructed near a major Gari processing centre where cassava peels had accumulated and polluted the environment.

\subsubsection{Innovation in the Use of Biomass}

The idea and know-how to convert cassava peel waste into income generating opportunity and improve environmental quality was the innovative contribution of this DDRD. To operationalize the idea, cassava peels were composted and subsequently used as substrate for the cultivation of mushrooms. Mushroom is an important food in diet of Ghanaians [4]. It is a valuable source of high 
quality proteins (21-40\%) dry weight, and rich in vitamins (B1, B2, B6, B12, C, D) [5-7]. Both the substrate and the mushrooms produced could be sold. This could be sufficient to keep farm families and the youth in business assuming there is ready market and the substrate as well as mushrooms are produced in large quantities. Through this intervention, the cassava peel waste is put to productive use and does not pollute the environment. Figure 2 shows the framework for converting cassava peels, which is a by-product or waste from the Gari/cassava chips processing activity and the waste substrate used as manure for crop production. The peels can also fed to livestock.

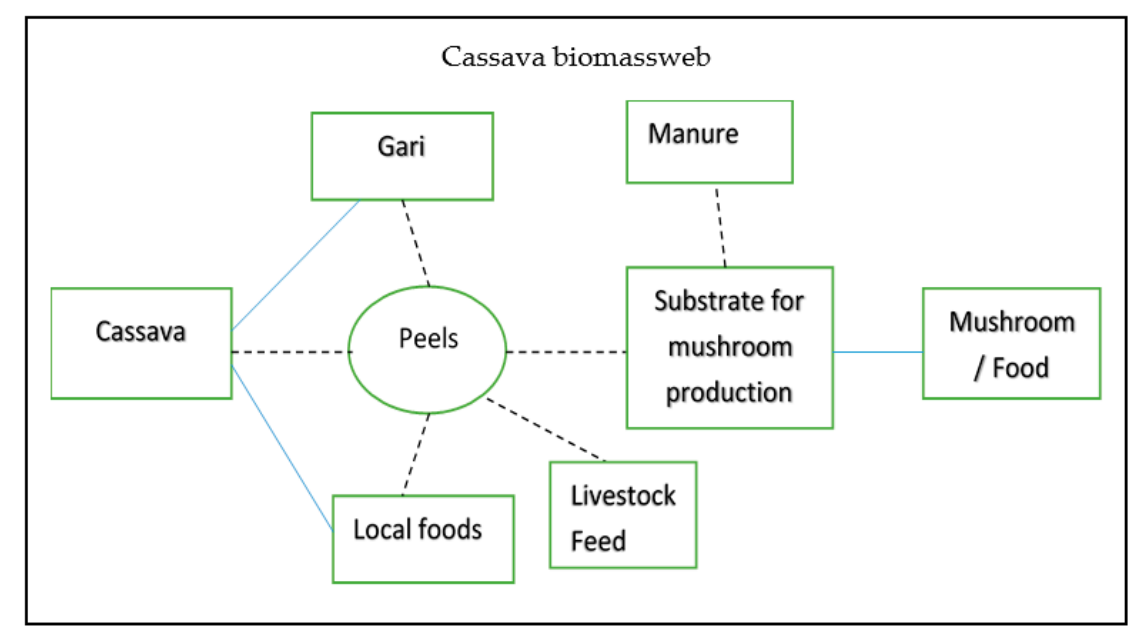

Figure 2. The flowchart illustrating conversion of cassava peel waste into substrate for mushroom cultivation and manure for agricultural production. Cassava peel waste also serves as livestock feed. (Dotted lines show productive uses of waste generated).

\subsubsection{Capacity Building}

For this project, about thirty (30) local women from a gari/cassava chips processing group and the youth of Gomoa community were trained on how to undertake mushroom cultivation. The training covered compost preparation leading to the generation of substrate, bagging, inoculation with spores (seed), incubation and harvesting of the mushroom. A mushroom house was constructed, and a solar dryer provided. According to the project managers there was the need to construct a structure for the mushroom production to be able to control the temperature which should not exceed 30 degrees Celsius, and also keep the room humid. This is consistent with other studies that have found an increase in temperature of 40-60 degree celcius likely to kill the mycelium in less than $24 \mathrm{~h}[4,8]$.

Trainees were also trained on how and where to market mushrooms. Since mushroom is currently produced on a small scale, the local markets and interested individual mushroom consumers were the main market options explored. Training was conducted by a consultant who was hired by the implementers Women in Agricultural Development (WIAD).

\subsubsection{Delivery of the Project and Adoption}

The concept of converting cassava peel waste to mushrooms for food and income is theoretically easy to adopt. Interactions with participants who were trained revealed they had understood how the concept is operationalized. However, many had the notion that a mushroom house is needed to operationalize this innovation. In which case, they felt financially handicapped to truly benefit from this innovation. To ensure the sustainability of the innovation, there should be (1) small-scale production of substrate from cassava peels using simple home-based materials and subsequently following up with the rest of the processes, and (2) private sector investments in constructing a mushroom house for the mass production of substrate for sale to small-scale mushroom producers. 


\subsection{Development of Plantain Biomass into Composite Flour for Traditional Foods and Bakery Products, Ghana}

\subsubsection{Demand Driven Research Planning}

Researchers from the Food Research Institute of the Centre for Scientific and Industrial Research (CSIR-FRI) Ghana, identified the need for this project in response to high postharvest losses of plantain and the need to convert plantain biomass into composite flour which could substitute wheat in the production of local foods and provide highly nutritious foods. Local food processors were trained in plantain processing technologies of converting plantain into composite flour for various traditional foods such as plantain fufu and value-added products for making of bakery products such as plantain chips, cakes, pies, bread and doughnuts.

\subsubsection{Innovation in the Use of Biomass}

Plantain is highly nutritious, provides rich dietary energy, and contains micronutrients such as carotenes, ascorbic acid, as well as minerals such as iron, potassium, zinc, calcium, and phosphorus [9]. Processing plantain into composite flour during plantain peak season when it is readily available on the market and prices are moderate will help reduce postharvest losses which are estimated at $20 \%$ at production level and 15\% at consumption level [9]. The composite flour can be stored for up to a year, hence can serve as a convenient raw material for making bakery products. The composite flour can serve as a substitute for wheat flour which is a major import commodity in Ghana. Currently Ghana imports about 700,000MT of wheat annually. Usage of plantain composite flour in bakery products will reduce importation of wheat flour. The plantain peels can serve as food for feeding livestock and as raw material for local soap industries (Figure 3).

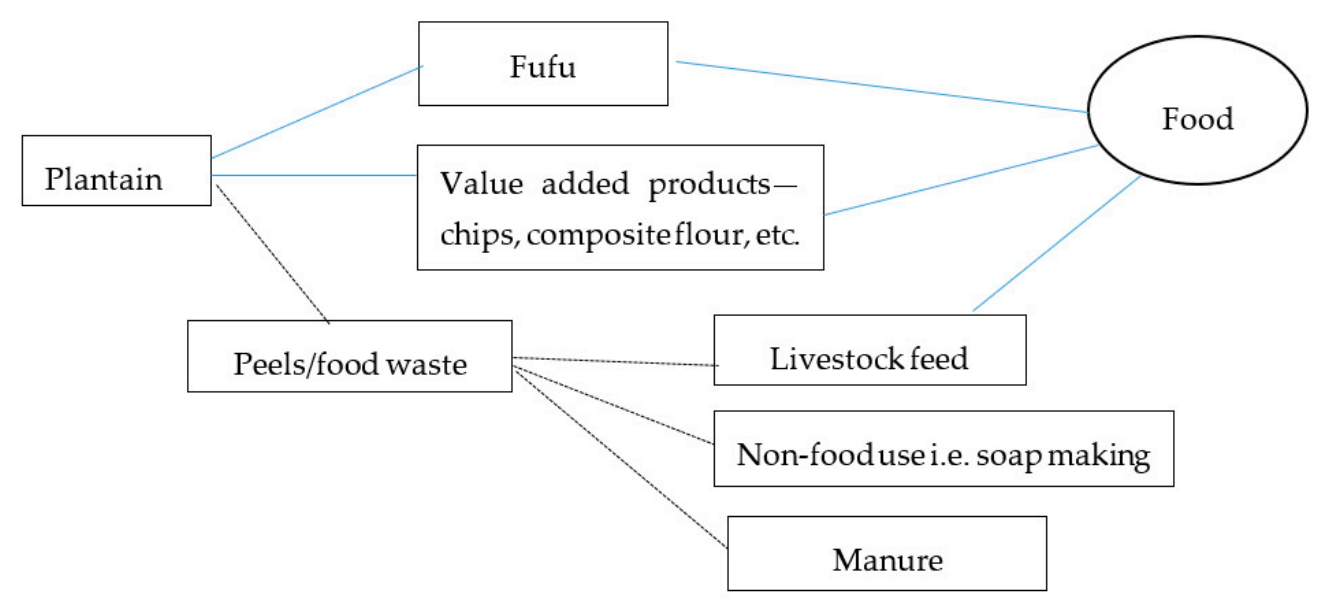

Figure 3. Plantain biomass value web (Dotted lines show productive uses of waste generated).

\subsubsection{Capacity Building}

About 117 local food processors were trained in converting plantain into composite flour and adding value to plantain products and developing better market linkages for plantain products. The technology is easy to adopt as it involved locally sourced materials and simple processing steps of boiling plantain, milling and drying to get the plantain flour. It does not require a huge start-up capital hence can be started on a small scale. Because the adoption of new technologies is likely to occur when individuals perceive some relevant advantage over an existing innovation or status quo, and such an innovation is compatible with existing practices and not too complex as well as offering observable results [10]. The initial start-up package for this project consisted of $1 \mathrm{~kg}$ of composite flour supplied to each beneficiary to encourage uptake of the technology. Beneficiaries reported uptake of the technology to have resulted in higher incomes as the addition of the plantain flour increased volumes of products and thereby increased their profits. Also, the project created jobs for some women 
who otherwise had no source of income. It was not immediately apparent what the level of adoption of the plantain value addition techniques and marketing strategies acquired from the CSIR-FRI team is. It appears too soon to notice measurable levels of adoption of the techniques. Adoption happens over time depending on the individual's decision to take up innovation [11], and the availability of resources, which in this case is seasonal with peak and minor seasons.

\subsubsection{Delivery of the Project and Adoption}

Widespread adoption and production of plantain composite flour is however hindered by the lack of access to milling machines and mechanized or solar dryer units to commercialize production. Current production level is on small-scale using corn milling machines and sun-drying which is challenged during rainy season. Innovative ways to assist in increasing adoption of the technology and commercializing the plantain composite floor production is therefore essential. This has to do with addressing the underlying challenge of acquiring milling machinery purposely for processing plantain into composite flour. Also, providing solar or mechanical drying units for efficiently drying the flour especially during the raining season which is also the peak season for plantain production. The beneficiaries can be organized into groups to mobilize funds for the purchase of milling machine and mechanical or solar drying unit. The group could go into commercial plantain flour production which members could purchase for their bakery production or food preparations. A private investor could also profit greatly by introducing milling machines and a solar dryers in the peak plantain growing areas. These aside, some easy to adopt strategies such as plantain chips production are already being utilized widely in major urban centers across the country.

\subsection{Bamboo Leaf as Fodder for Livestock Production, Ghana}

\subsubsection{Demand Driven Research Planning}

The idea of introducing bamboo as an alternative fodder for livestock feeding was developed by the International Network for Bamboo and Rattan (INBAR), with financial support from FARA and ZEF within the BiomassWeb project. Livestock production in Ghana is limited by access to sustainable feed supply especially during the dry season. The evergreen nature of bamboo and its high nutritive content makes it an ideal fodder especially during the dry season when tree leaves and grasses dry up and are burnt by frequent bush fires. INBAR piloted a bamboo-based agroforestry model in the dry semi-deciduous zone of Ghana to promote the integration of bamboo into indigenous cropping systems to meet socioeconomic needs and provide fodder for livestock. Experimental bamboo feeding trials were set up to explore the consumption patterns and digestibility of bamboo fodder and evaluate growth and health of livestock fed with bamboo leaves either as sole feed or feed supplement.

\subsubsection{Innovation in the Use of Biomass}

In Ghana, bamboo use as fodder is largely unknown. There is insufficient awareness of bamboo utilization as fodder throughout Ghana. Partey et al. [12] in their study on perception of bamboo leaf as fodder for livestock production found less than $26 \%$ of respondents were aware of use of bamboo leaves as fodder. However, the evergreen nature of bamboo and its high nutritive content -i.e., rich crude protein (9-19\%) and content of crude fiber (18-34\%) - makes it an ideal fodder especially during the dry season [13]. Successful introduction of bamboo as an alternative feed stock will ensure that livestock have fresh fodder all year round, thereby encouraging livestock production. The bamboo stems will provide fuelwood, while the young regenerated shoots can be consumed as food. Bamboo can also be used in alley cropping systems to boost food production while at the same time stabilizing the soils and minimizing environmental impacts including mitigation and adaptation to climate change (Figure 4). INBAR has introduced two bamboo species from India (Bambusa balcooa or beamer bamboo) and Ethiopia (Oxythenanthera abyssinica). Both species are drought and fire tolerant. Fire and droughts are typical of the forest-savannah transition belt and the savannah zone of Ghana. 


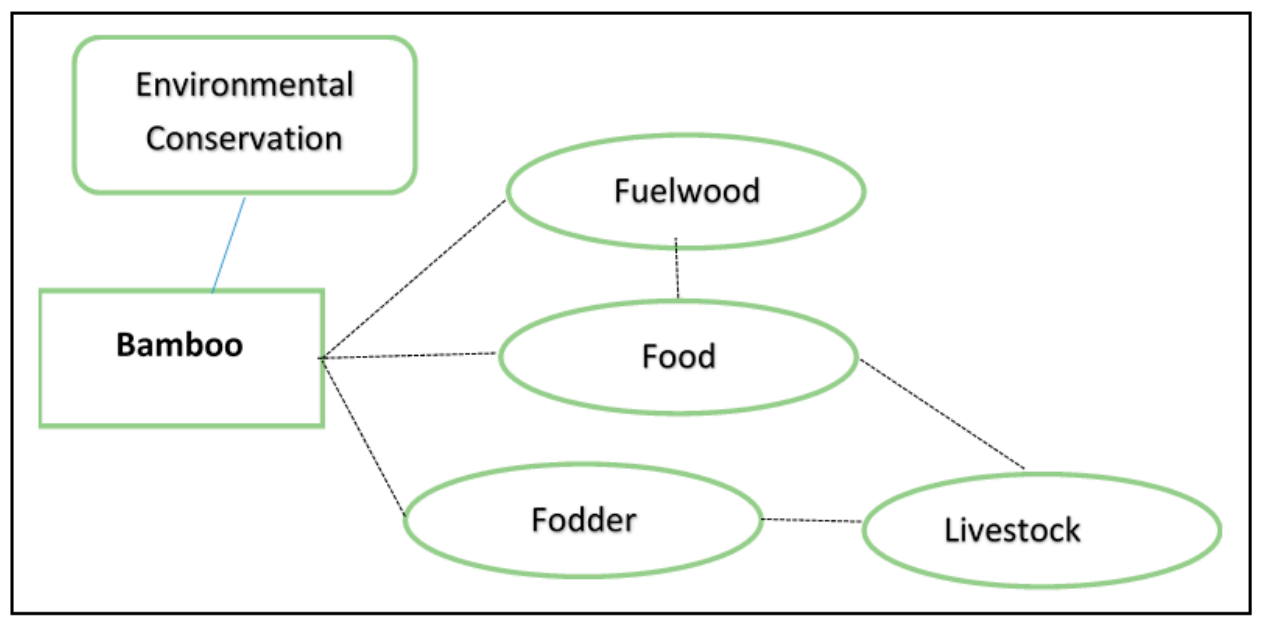

Figure 4. Bamboo agroforestry and bamboo fodder for livestock production (Dotted lines show productive uses of waste generated).

\subsubsection{Experimental Set-Up}

The bamboo feeding trial experiment was set as a completely randomized design experiment with two replications. Plant fodder for goats was the main treatment and consisted of three feed types: (1) Bamboo leaves, (2) Grass-sugar cane grass or Saccharum spp., and (3) Leaves of Millettia species and Gmelina arborea. Six goats were used in the experiment, with two assigned to each of the fodder types above. The data was collected on weekly weights of goats, feacal matter, urine and blood samples. The study revealed that bamboo is acceptable to the sheep and was completely consumed when offered ad libitum and therefore using it as a feed supplement can increase feed intake of the basal diets by $40 \%$ and increase the weight of sheep by $2.31 \mathrm{~kg}$ [14]. The Bamboo crude protein (CP) of $124 \mathrm{~g} / \mathrm{kg}$; ash—80 g/kg; neutral detergent fibre (NDF)— $464 \mathrm{~g} / \mathrm{kg}$ compares well with cowpea haulm, a leguminous haulm, with a $\mathrm{CP}$, ash, NDF, and gas production (GP) of 124-268; 89;419 g/ kg, respectively, except the gas production (GP), which is 2 times lower than cowpea haulm [15]. The study however finds that the bamboo used as supplement led to a reduction in the blood parameters measured at the end of the experiment, the RBC $\left(5.8-8.0 \mathrm{~L}^{-1}\right)$, total protein $\left(63-70 \mathrm{~g} \mathrm{dL}^{-1}\right)$, and albumin $\left(23-28 \mathrm{~g} \mathrm{dL}^{-1}\right)$ compared well with RBC $\left(6.4-9.9 \mathrm{~L}^{-1}\right)$, total protein $\left(63-71 \mathrm{~g} \mathrm{dL}^{-1}\right)$ when sheep were fed with sorghum stover and dried poultry droppings, except for the albumin which was 1.5 times lower than those reported by the researchers [14]. Despite the comparably higher $\mathrm{CP}, \mathrm{GP}$, ash and the positive influence on growth performance, bamboo should be fed alongside with leguminous for ages in an attempt to meet the energy-protein requirement of the animals and also improve the health status of the animals through the supply of minerals and protein [14].

\subsubsection{Delivery of the Project and Adoption}

For bamboo leaves to be adopted and used as fodder by local subsistence and commercial livestock farmers, there is the need for massive awareness creation and public education at the grassroots level where the need for such fodder will be most required. Key to this process will be the sustainable availability of the bamboo resources. INBAR has undertaken efforts to ensure sufficient bamboo material is available for the provisioning of leaves as fodder by establishing bamboo plantations in selected communities. There are plans to expand the bamboo plantation cover in the country. Hence, there is significant promise that sufficient bamboo fodder will be made available for large scale livestock production in the future. So far more than $50 \%$ of farmers in bamboo growing areas in Ghana have demonstrated their willingness to accept bamboo as a livestock feed [14]. The bamboo fodder should however be supplemented by a leguminous fodder to supply both energy, protein and minerals for the animals to meet their nutrient requirement [14]. 


\subsection{Production of Bio-Plastics and Bio-Gels from Agricultural Waste to Promote Their Biomassweb} Values, Nigeria

\subsubsection{Demand Driven Research Planning}

The project idea was conceptualized through collaborative effort by researchers from different institutions both national and international to address the challenge of environmental pollution from plastic waste in Africa using waste from agricultural products such as cassava, banana, maize to produce bio-gels and bio-plastics that are biodegradable. The institutions involved in the demand-driven research are the Federal Institute of Industrial Research Oshodi (FIIRO), International Institute for Tropical Agriculture (IITA), and University of Ibadan. The collaboration among the institutions ensured that different partners pursued various aspect of the research and analysis. Funding for the research was provided by Forum for Agricultural Research in Africa (FARA) and Centre for Development Research (ZEF) under the BiomassWeb project.

\subsubsection{Innovation in the Use of Biomass}

Plastic waste disposal is a huge environmental burden in Africa and the world, polluting land, water and air. The alternative to synthetic plastic is bio-degradable plastics which is degradable by microorganisms and enzymes such as bacteria, algae and fungi. Such biodegradable plastics can reduce plastic waste in the environment. The research team in this DDRD project explored the use of various agricultural waste products to develop biodegradable plastics and bio-fuels (Figure 5).

The research team was successful in developing a protocol for the production of bio-plastics from starches obtained from cassava peels, acetic acid and glycerol (200:20:10) to form a good bioplastic resin [16]. The bio-plastics produced are highly degradable. Degradation of the bio-plastics at day 3 was approximately $14 \%$ after burying in soil and by day 12 , approximately 86 percent of the bio-plastic was degraded [16]. The team also successfully produced bioethanol using starch extracted from cassava peel and cellulose from corn cobs using acid hydrolysis and yeast fermentation. The average yield of bioethanol is $757.33 \mathrm{ml}$ for cassava peel and 595.56 for corn cobs from 3.55L and 3.35L of filtrates respectively [17]. The properties of bio-ethanol produced from the two samples compared favorably with the commercial ethanol [17].

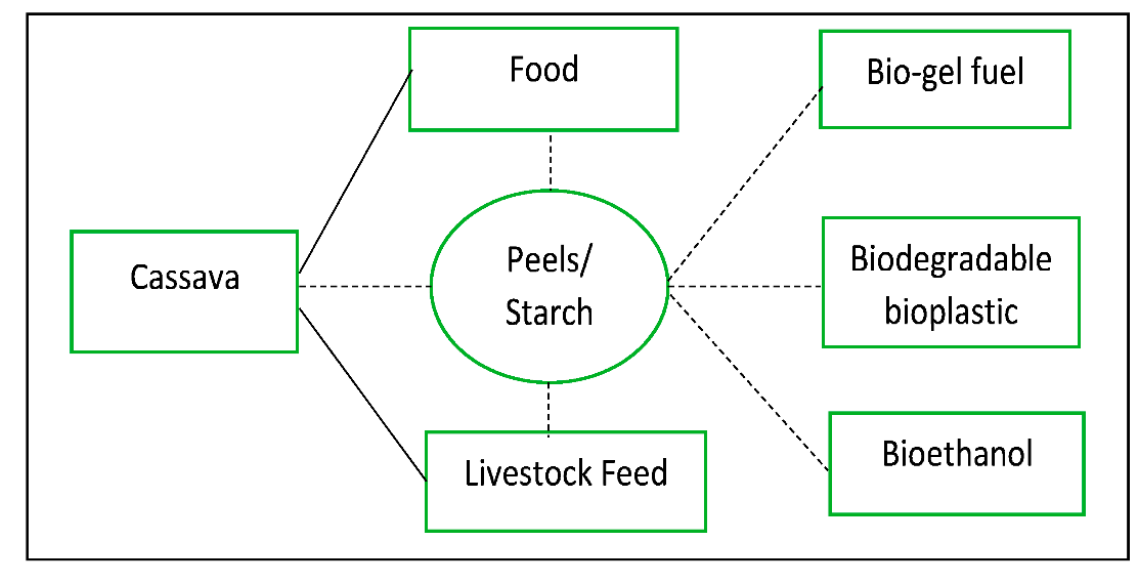

Figure 5. The flowchart illustrating conversion of cassava waste into bio-plastics, bio-ethanol and bio-gels. (Dotted lines show productive uses of waste generated).

\subsubsection{Capacity Building}

The research team presented their research findings at scientific conferences and workshops to disseminate research findings. A project dissemination workshop was organized to inform policy makers, manufacturers from the plastic industry and other researchers of the novel findings of the 
study. Two masters' students from the University of Ibadan were involved in the research study and trained on performing the experimental setup.

\subsubsection{Delivery of the Project and Adoption/Upscaling}

The research findings show evidence of the potential of using waste from agricultural products to address environment pollution. Scaling up bioplastic production will first need an economic feasibility of such production using a pilot scale. Such study will present a real life situation before commercial production [17]. In the case of ethanol gel, processing plants utilizing starch crop like maize, cassava and cellulose for ethanol are already in existence, however, most of them are large scale. There is a need to set-up micro/small scale plants for bio-gel production to ensure lower cost of production and even distribution at affordable price [17].

\subsection{Mass and Energy Balance Analysis of Pneumatic Dryers for Cassava and Development of Optimization} Models to Increase Competitiveness, Nigeria

\subsubsection{Demand Driven Research Planning}

This DDRD project implemented by The Federal University of Technology Akure (FUTA) addressed the inefficiencies of locally manufactured pneumatic flash dryer for processing of cassava into High Quality Cassava Flour (HQCF), and further identified new ways to improve the drying performance of the dryers. The project had the objectives of evaluating the performance of pneumatic flash dryer models operated by cassava processors in Nigeria using mass and energy balance analysis, and further modifying the flash dryer models to improve the drying efficiency and to develop a detailed engineering design of an efficient flash dryer model. The research team was composed of researchers from FUTA, Federal Institute of Industrial Research Oshodi (FIIRO), International Institute of Tropical Agriculture (IITA), and Kwara State University Ilorin who collaboratively embarked on the study to provide a solution to the inefficiencies in existing dryers for local manufacturers. Funding for the research was provided by Forum for Agricultural Research in Africa (FARA) and Centre for Development Research (ZEF) under the BiomassWeb project.

\subsubsection{Innovation in the Project}

The research team evaluated four design models of pneumatic flash dryers based on energy efficiency, specific heat consumption, thermal efficiency, heat losses to the ambient and heat losses via air outlets. The results of the study showed that existing models had a combination of both efficient and inefficient component parts which results in heat loss and low heat energy utilization. The inefficiencies identified on the existing dryers included the absence of insulation on the drying duct which facilitated greater loss, absence of feeder on some of the flash dryer models, improper design of the multiple cyclone which affect proper separation of product from the exhaust air and absence of heat control system on the burners [18].

An improved engineering design of a pneumatic flash dryer was designed by the researchers to regulate the heat loss and improve on the quality of HQCF produced. The modification included the introduction of insulation for reduction of heat losses, instrumentation circuit diagram for heat control system, and an efficient two passes heat exchanger system for maximum heat utilization. A prototype model design of the improved pneumatic flash dryer was developed and fabricated by the research team.

\subsubsection{Capacity Building}

A dissemination and training workshop was organized by the research team to disseminate information on the improved efficient pneumatic flash dryer for processing of High Quality Cassava Flour (HQCF). Fifty fabricators and engineers from South-West Nigeria participated in the workshop. 
Participants at the workshop were informed of the improved model design and the needed improvement on the existing dryers to improve drying efficiency.

\subsubsection{Delivery of the Project and Adoption/Upscaling}

To transfer the knowledge on manufacturing efficient pneumatic flash dryers to equipment manufacturers, trainings in the development of detailed engineering design and fabrication of the prototype improved flash dryer need to be carried out. The trainings should include hands-on practical session for manufacturers on how to fabricate the improved pneumatic flash dryer model.

3.6. Exploring Potentials of the Bamboo Sector for Employment and Food Security in Ethiopia: An Institutional Analysis of Bamboo-Based Valueweb, Ethiopia

\subsubsection{Demand-Driven Research Planning}

The idea for implementation of the DDRD project was conceptualized by researchers from the institute of economic development, Ethiopia and the University of Hohenheim, Germany. The primary objective of the research project was to provide holistic insights into the current status and future potentials of the bamboo sector in Ethiopia in order to enhance sustainable livelihoods and employment generation. The researchers surveyed 468 households from two major bamboo growing regional states in Ethiopia-Amhara and Benishangul Gumuz. The research findings are to inform policy decision makers on the potential benefits of promoting the bamboo sector for socio-economic benefits. This research was researcher led, incorporating local people perceptions. The funding for the research study was provided by provided by Forum for Agricultural Research in Africa (FARA) and Centre for Development Research (ZEF) under the BiomassWeb project.

\subsubsection{Innovation in the Project}

Ethiopian rural households earn a significant part of their livelihood from natural resources mostly forest products [19]. Bamboo is such a natural resource which serves as a source of energy, fodder, food, construction material and handicrafts. Ethiopia's natural bamboo forest, the largest in the African continent, is estimated to be around one million hectares, of which 850,000 hectares are lowland and 350,000 hectares are highland bamboo varieties [19-21]. Even though Bamboo has significant benefits, the bamboo sector has received little attention and its potential contribution to the economy has been underexploited. This situation is similar to that of many African countries including Ghana [12,22,23], which calls for the need creation of awareness among the local people and policy makers to promote the bamboo sector to enhance livelihoods and enhance sustainability of the environment. This DDRD research project was setup to contribute to this agenda.

The findings from the study [19] revealed that poor rural families preferred to engage in bamboo production requiring few resources. Also, market prices of bamboo culms significantly increase the probability of employment in bamboo sector, and the probability of the variation in the income from bamboo of rural households. Bamboo has the potential to ensure food security through provision of higher incomes and better food security of poor rural smallholder farmers. Further the rapid growth of bamboo and short growing cycle makes bamboo a suitable option as income source during food shortages.

\subsubsection{Capacity Building}

The findings of this study seek to create awareness on the potential benefit of the bamboo in addressing food security, creating employment which will lead to an increase in income and wellbeing in the livelihood of people in communities where bamboo grows. 


\subsubsection{Delivery of the Project and Adoption/Upscaling}

To tap into the full potential of bamboo, a collective action of action of actor in the bamboo biomassweb is required. This includes the engagement of governments, NGOs, local farmers, processors and private sector. There is the need to create awareness on the diverse benefit of bamboo, improved methods of growing and extracting culms, and adoption of improved technologies.

\section{Discussion}

Demand-driven research process involve several actors and beneficiaries at each stage of the process, with the ultimate benefit of enhancing ownership and increasing applicability of research [24]. Practical operationalization of demand-driven research planning process is limited by the level of perspective of actors on the innovation and capacity to fully participate and operationalize the demand-driven research [24]. For the case studies presented in this paper researchers identified the need for the innovation to address identified challenges and supplied or transferred knowledge and innovation to the end-users. The identification of the challenge was done through surveys, or consultations with the end-users. This was followed by developing proposals to source funds from funding agencies who prioritized the identified research area/ innovation as key to engendering development. Thus, the funding agency (FARA/ZEF) demands the knowledge and innovation on behalf of the end-users.

In contrast, DDRD in the advanced economies are spearheaded by the end-user, in this respect the farmer. The end-users fundamentally identify a research problem, mobilize funds from among end-users, private enterprises/beneficiaries or the public sector (Government) to solve the problem and contracts a researcher or an agency to implement and/or solve the problem. End-users in this case have the opportunity to contribute knowledge and innovations into the DDRD, although more often the final outcome of the DDRD program does not adequately reflect end-users' (farmers) needs due to influence by several actors in the DDRD planning process [25]. This implies that even in the developed economies where DDRDs are end-user demanded in theory, in practice, the influence of other stakeholders in the planning compromise the power of end-users. Active participatory methods must be pursued if end-user power in DDRDs are to be greater priority.

Implementation was done together with the end-users through trainings, hands-on experiences, experimental set-up and surveys. For the innovation generated to be transferred, it should respond to the needs of the beneficiaries or end-users. As Rogers [10] indicates, new innovations are likely to occur in response to economic opportunity or scarcity.

In the case studies presented in this paper (Table 2), the innovations in the use of biomass of plantain responded to reducing postharvest losses, substituting wheat which is imported in the preparation of bakery products, and also creating jobs and increasing incomes [9]. The use of drought tolerant and fire resistant bamboo biomass highlights the multiple uses of the bamboo in feeding livestock, especially in the dry season, inter-alley cropping to boost food production and stabilizing the soils used as fuelwoods because of its potential for energy recovery to be used as energy source compared to other woody biomass [13]. The bamboo shoot served as a food source for locals. However, there is low awareness among end-users even though there is evidence of bamboo contributing to improving food security. This calls for the need to create awareness on the benefit of bamboo and to involve policy makers and other stakeholders in the bamboo valueweb [12,19].The innovation in the use of cassava biomass showed the conversion of cassava peels which are generated waste from cassava processing into substrate for cultivation of mushroom which were sold to raise income and included in household food. 
Table 2. Innovation in Demand Driven Research and Development Project and implementation Modalities.

\begin{tabular}{|c|c|c|c|c|c|}
\hline DDRD Project & Implementing Institution & $\begin{array}{c}\text { Planning and Scope of } \\
\text { Project } \\
\text { How Was the Process } \\
\text { Planned or } \\
\text { Conceptualized? }\end{array}$ & $\begin{array}{l}\text { Innovation in the Use of Biomass } \\
\text { What Is Innovative about the } \\
\text { Process? } \\
\text { Number of Research Products } \\
\text { Generated }\end{array}$ & $\begin{array}{c}\text { Capacity } \\
\text { Building/Experimental Setup } \\
\text { How Was } \\
\text { Training/Experimental Set Up } \\
\text { Done? }\end{array}$ & $\begin{array}{c}\text { Delivery of Project and Adoption } \\
\text { How Was Innovation Uptake? } \\
\text { Sustainability? }\end{array}$ \\
\hline $\begin{array}{l}\text { Using cassava peels for } \\
\text { mushroom production }\end{array}$ & $\begin{array}{l}\text { Ministry of Food and Agriculture, } \\
\text { Women in Agricultural } \\
\text { Development, (WIAD) Ghana. } \\
\text { WIAD is a department of the } \\
\text { Ministry of Food and Agriculture. } \\
\text { It has National, Regional and } \\
\text { District offices across Ghana. It is } \\
\text { very active at local level }\end{array}$ & $\begin{array}{l}\text { Researchers identified } \\
\text { innovation and facilitated } \\
\text { implementation of process } \\
\text { for end users (local women } \\
\text { and youth) }\end{array}$ & $\begin{array}{l}\text { Conversion of cassava peels which are } \\
\text { waste from processing of cassava chips } \\
\text { into substrate for production of } \\
\text { mushroom to improve household food } \\
\text { security, generate income, minimize } \\
\text { environmental degradation } \\
\text { A manual on production of mushroom } \\
\text { A video used in farmer training }\end{array}$ & $\begin{array}{l}\text { Researchers trained } \\
\text { beneficiaries on usage of } \\
\text { innovative technology of using } \\
\text { cassava peels in compost as a } \\
\text { substrate for mushroom } \\
\text { production. Constructing of } \\
\text { low-cost building for } \\
\text { mushroom with local materials. }\end{array}$ & $\begin{array}{l}\text { Adoption low. A mushroom house } \\
\text { needed to be constructed to } \\
\text { operationalize this innovation, which } \\
\text { comes as a cost. } \\
\text { There is the need for more } \\
\text { cost-effective approaches using a group } \\
\text { based approach with access to } \\
\text { microfinance. }\end{array}$ \\
\hline $\begin{array}{l}\text { Development of plantain } \\
\text { biomass into composite } \\
\text { flour for traditional foods } \\
\text { and bakery products }\end{array}$ & $\begin{array}{l}\text { Centre for Scientific and Industrial } \\
\text { Research-Food Research } \\
\text { Institution (CSIR-FRI), Ghana. This } \\
\text { is an institute of the National } \\
\text { Agricultural Research Institute. Its } \\
\text { mandate is mainly of research. It } \\
\text { works through other units (like } \\
\text { WIAD) for technology outreach } \\
\text { and adoption. }\end{array}$ & $\begin{array}{l}\text { Researchers identified need } \\
\text { to process plantain into } \\
\text { composite flour and trained } \\
\text { local processors and women } \\
\text { in use of the technology. }\end{array}$ & $\begin{array}{l}\text { Plantain processed into composite } \\
\text { flour to reduce on postharvest losses } \\
\text { and a potential subsite for wheat in } \\
\text { bakery products. } \\
\text { Seven knowledge products were } \\
\text { generated, three peer reviewed articles, } \\
\text { manuals, posters }\end{array}$ & $\begin{array}{l}\text { Researchers trained } \\
\text { beneficiaries on converting } \\
\text { plantain biomass into } \\
\text { composite flour, adding value } \\
\text { to plantain products, linkage to } \\
\text { markets. }\end{array}$ & $\begin{array}{l}\text { Uptake of technology low. Hindered by } \\
\text { the lack of access to milling machines } \\
\text { and mechanized and solar dryer units. } \\
\text { Locally fabricated milling machines } \\
\text { specifically for milling of plantain } \\
\text { should be developed and also solar } \\
\text { drying units. Processors could access } \\
\text { and use the facility at a fee. } \\
\text { WIAD could mobilize the women into } \\
\text { groups to acquire and manage the } \\
\text { milling and drying units. }\end{array}$ \\
\hline $\begin{array}{l}\text { Bamboo leaf as fodder for } \\
\text { livestock feeding }\end{array}$ & $\begin{array}{l}\text { International Bamboo and Rattan } \\
\text { Organization (INBAR), Ghana. } \\
\text { INBAR is an Intergovernmental } \\
\text { organization working in } \\
\text { Agroforestry-focus on Bamboo } \\
\text { and Rattan. Its regional office in } \\
\text { West Africa is in Ghana. It works } \\
\text { with research organizations, local } \\
\text { NGOs and government at the } \\
\text { frontline }\end{array}$ & $\begin{array}{l}\text { Researcher led survey and } \\
\text { experimental set-up. }\end{array}$ & $\begin{array}{l}\text { Drought tolerant and fire-resistant } \\
\text { bamboo used for feeding livestock in } \\
\text { the dry season; inter-alley cropping to } \\
\text { boost food production and stabilizing } \\
\text { the soils, used as fuelwood. } \\
\text { A peer reviewed article, a study report }\end{array}$ & $\begin{array}{l}\text { Bamboo feeding trial } \\
\text { experiment set as a completely } \\
\text { randomized design experiment } \\
\text { with two replications }\end{array}$ & $\begin{array}{l}\text { Experimental trials show bamboo is a } \\
\text { viable feed supplement for livestock } \\
\text { feeding } \\
\text { Need to supplement bamboo feed by a } \\
\text { leguminous fodder to supply both } \\
\text { energy, protein and minerals for the } \\
\text { animals to meet their nutrient } \\
\text { requirement } \\
\text { There is the need for education and } \\
\text { sensitization on the locals on uses of } \\
\text { bamboo. }\end{array}$ \\
\hline $\begin{array}{l}\text { Production of bio-plastics } \\
\text { and bio-gels from } \\
\text { agricultural waste to } \\
\text { promote their } \\
\text { biomassweb values }\end{array}$ & $\begin{array}{l}\text { Federal Institute of Industrial } \\
\text { Research Oshodi (FIIRO), } \\
\text { International Intitute for Tropical } \\
\text { Agriculture (IITA), and University } \\
\text { of Ibadan. All three institutions are } \\
\text { located in Nigeria }\end{array}$ & $\begin{array}{l}\text { Researchers responded to } \\
\text { the need to address the } \\
\text { challenge of environmental } \\
\text { pollution from plastic waste } \\
\text { in Africa using waste from } \\
\text { agricultural products }\end{array}$ & $\begin{array}{l}\text { Development of a protocol from } \\
\text { cassava peel starch for the production } \\
\text { of bio-gel fuel and biodegradable } \\
\text { plastic. } \\
\text { Study reports and peer reviewed } \\
\text { articles }\end{array}$ & $\begin{array}{l}\text { Dissemination workshops to } \\
\text { share findings with policy } \\
\text { makers, manufacturers and } \\
\text { researchers. Training of } \\
\text { research scientist. }\end{array}$ & $\begin{array}{l}\text { Scaling up bioplastic production will } \\
\text { first needs an economic feasibility of } \\
\text { such production using a pilot scale. } \\
\text { There is need to set-up micro/small } \\
\text { scale plants for bio-gel production to } \\
\text { ensure lower cost of production and } \\
\text { even distribution at affordable price }\end{array}$ \\
\hline
\end{tabular}


Table 2. Cont.

\begin{tabular}{|c|c|c|c|c|c|}
\hline DDRD Project & Implementing Institution & $\begin{array}{c}\text { Planning and Scope of } \\
\text { Project } \\
\text { How Was the Process } \\
\text { Planned or } \\
\text { Conceptualized? } \\
\end{array}$ & $\begin{array}{l}\text { Innovation in the Use of Biomass } \\
\text { What Is Innovative about the } \\
\text { Process? } \\
\text { Number of Research Products } \\
\text { Generated }\end{array}$ & $\begin{array}{c}\text { Capacity } \\
\text { Building/Experimental Setup } \\
\text { How Was } \\
\text { Training/Experimental Set Up } \\
\text { Done? }\end{array}$ & $\begin{array}{c}\text { Delivery of Project and Adoption } \\
\text { How Was Innovation Uptake? } \\
\text { Sustainability? }\end{array}$ \\
\hline $\begin{array}{l}\text { Mass and energy balance } \\
\text { analysis of pneumatic } \\
\text { dryers for cassava and } \\
\text { development of } \\
\text { optimization models to } \\
\text { increase competitiveness }\end{array}$ & $\begin{array}{l}\text { Federal University of Technology } \\
\text { Akure (FUTA), Nigeria }\end{array}$ & $\begin{array}{l}\text { Researchers identified the } \\
\text { need to design an efficient } \\
\text { pneumatic flash dryer to } \\
\text { address inefficiencies in } \\
\text { existing models. }\end{array}$ & $\begin{array}{l}\text { An improved engineering design of } \\
\text { pneumatic flash dryer was designed by } \\
\text { the researchers to regulate the heat loss } \\
\text { and improve on the quality of HQCF } \\
\text { produced. The modification included } \\
\text { the introduction of insulation for } \\
\text { reduction of heat losses, } \\
\text { instrumentation circuit diagram for } \\
\text { heat control system, and an efficient } \\
\text { two passes heat exchanger system for } \\
\text { maximum heat utilization. } \\
\text { Study reports and peer reviewed } \\
\text { articles are output of the project. }\end{array}$ & $\begin{array}{l}\text { Fifty fabricators and engineers } \\
\text { from South-West Nigeria were } \\
\text { trained on the design of the } \\
\text { improved efficient pneumatic } \\
\text { flash dryer. }\end{array}$ & $\begin{array}{l}\text { Uptake of the technology will require } \\
\text { hands-on practical session for } \\
\text { manufacturers on how to fabricate the } \\
\text { improved pneumatic flash dryer } \\
\text { model. }\end{array}$ \\
\hline $\begin{array}{l}\text { Exploring potentials of } \\
\text { the bamboo sector for } \\
\text { employment and food } \\
\text { security in Ethiopia: An } \\
\text { institutional analysis of } \\
\text { bamboo-based valueweb }\end{array}$ & $\begin{array}{l}\text { YOM Institute of Economic } \\
\text { Development (YIED), Ethiopia }\end{array}$ & Researcher-led survey & $\begin{array}{l}\text { A study reports and peer reviewed } \\
\text { articles are outputs of the research } \\
\text { study. }\end{array}$ & $\begin{array}{l}\text { Survey of } 468 \text { households from } \\
\text { two major bamboo growing } \\
\text { regional states in } \\
\text { Ethiopia-Amhara and } \\
\text { Benishangul Gumuz. }\end{array}$ & $\begin{array}{l}\text { Need to create awareness on the } \\
\text { diverse benefit of bamboo, improved } \\
\text { methods of growing and extracting } \\
\text { culms, and adoption of improved } \\
\text { technologies. }\end{array}$ \\
\hline
\end{tabular}


There is the need for more cost-effective approaches using a group-based approach with access to microfinance to scale up the adoption of the using cassava peels for mushroom production. Production of bioplastic and bio-fuels from cassava peel starch is innovative and addresses a serious environmental problem of plastic pollution. For this innovation to be up-scaled there is the need for an economic feasibility of such production using a pilot scale. Also, there is the need to set up micro/small scale plants for bio-gel production to ensure lower cost of production and even distribution at affordable prices. The research team from FUTA developed an improved engineering design of pneumatic flash dryer to regulate the heat loss and improve on the quality of HQCF produced. The modification included the introduction of insulation for reduction of heat losses, instrumentation circuit diagram for heat control system, and an efficient two passes heat exchanger system for maximum heat utilization. Uptake of the technology will require hands-on practical session for manufacturers on how to fabricate the improved pneumatic flash dryer model.

These innovations even though identified by researchers addressed needs of the end-users which necessitated the buy-in of the end-users. It must, however, be noted that even though there was a need for the innovation to address a pressing challenge of the end-users, this was not sufficient. The adoption and uptake of the innovation depended on the technological and technical support received by the end-users and in some of the project the reliable supply of biomass (plantain, bamboo, cassava). For instance, in the case of bamboo biomass, there is the need to expand bamboo plantation cover in the area and across the livestock growing regions in the country. In the use of plantain biomass, operationalization of the innovation was hindered by the availability of technology and machinery. The end-users needed to have local milling machines and solar drying units to effectively take up the technology and upscale production of the plantain composite flour. The case of use of cassava biomass required end-users to have a housing structure for the mushroom production (Table 2). In designing demand-driven research and development projects, the uptake by the end-users is crucial and such technology and infrastructural needs should have been factored into the implementation and funding plan for the full uptake of the technology.

Technical support in the uptake of innovations is also essential in the supply-side of the demand-driven research. This was fulfilled by the researchers providing training or education to end-users on the operationalization and processes of the innovations as well as the relevance and benefit of the innovation. However, the decision to take up an innovation largely depends on the innovation itself addressing an economic opportunity or scarcity, knowledge and understanding of the end-user, the end-users decision to adopt and the end-user actually confirming and implementing the innovation. Time is a key factor in adoption [11]. Adoption of innovation happens over time. The immediate results on the level of uptake of innovation of the demand-driven research could therefore not be fully assessed as the projects implementation phase lasted between three to nine months.

Lessons learnt from the DDRD projects include:

1. Innovative thinking such as in the WIAD, University of Ibadan bioplastic, and biofuel projects can lead to improved environmental conditions by reducing environmental pollution.

2. Waste can be used profitably by carefully process it to reduce the environmental externalities, reduce the land area required for its disposal, and provide income.

3. Extending the shelf life of perishable products and thus minimizing postharvest losses can add value and alleviate poverty.

4. Bamboo has the potential to serve as an alternative feed for livestock farmers especially in the lean season when feed is scarce. This could boost meat production, increase food and nutritional security and alleviate poverty.

5. Uptake of the technology such as improved design of pneumatic flash dryers by the research team from FUTA will require hands-on practical session for manufacturers on how to fabricate the improved pneumatic flash dryer model. 
6. Training and dissemination of research findings and output is essential to generate the desired impact and outcome of the projects.

\section{Conclusions}

The type of the beneficiary organisation (research organisation and government technical unit) is an important variable to ensuring stakeholder involvement and reporting. The experience implementing the demand-driven projects (i.e. small grants) generated several research outcomes, perhaps much more than the value of the investments. We observe some significant differences in the level of participation of communities and end-users in the various projects. In the case of WAID, we observe strong community participation (albeit low involvement of women) as well as community/district level extension agencies. In the other DDRD projects (INBAR, FUTA, UI YIED, CSIR), we observe relatively less participation of end users in actual implementation of the project. These projects were mainly research based enquiry, implemented by researchers from the institutions. Trainings, surveys and dissemination workshops to some extent provided some level of participation for the end users.

There were significant differences in the knowledge products produced from the DDRD projects, more from the research oragnisations (CSIR, YIED, FUTA, UI and INBAR) compared to the department of the Ministry of Agriculture (WIAD). It is also observed that research institutions often collaborated with other research institutions in implementing the research project. All the project embarked on finding innovative ways of addressing pressing socio-economic and environmental challenges exploring the use of biomass.

In summary,

(1) Innovations around the use of biomass was led by researchers, funded by a donor who demanded on behalf of end-users to address challenges and create opportunity around the use of biomass.

(2) Innovation opportunities were generated around the use of biomass in addressing challenges of postharvest losses of plantain, income generation from conversion of cassava peels into mushroom production, use of bamboo for livestock feeding in dry season and for promoting food security, production of bioplastics and bio-fuels from cassava peels, and development of improved efficient model of pneumatic flash dryers.

(3) However, these innovations were not sufficiently adopted. The adoption/uptake and operationalization depended on the availability of reliable supply of biomass, technological and technical support. Adoption of the innovation around the biomass in the end depends on the end-users understanding the innovation, decision to adopt and actually adopting the innovation.

Author Contributions: All authors contributed equally to the conceptualization and writing of manuscript.

Funding: This research was funded by the German Federal Ministry of Education and Research (BMBF) through the collaborative project "Improving food security in Africa through increased system productivity of biomass-based value webs." This project is part of the GlobE-Research for the Global Food Supply programme (Grant No. 031A258H).

Acknowledgments: This paper presents six demand-driven research and development projects implemented in Ghana within the BiomassWeb project which is coordinated by Forum for Agricultural Research in Africa (FARA), Ghana and the Centre for Development Research (ZEF), Germany. We acknowledge the financial support from the German Federal Ministry of Education and Research (BMBF) supported with funds from the German Federal Ministry for Economic Cooperation and Development (BMZ). We also acknowledge support of all project partners.

Conflicts of Interest: The authors declare no conflict of interest. 


\section{References}

1. Forum for Agricultural Research in Africa FARA. Science Agenda for Agriculture in Africa (S3A): "Connecting Science" to Transform Agriculture in Africa; Forum for Agricultural Research in Africa (FARA): Accra, Ghana, 2014.

2. Mansuri, G.; Rao, V. Community-based and-driven development: A critical review. World Bank Res. Obs. 2004, 19, 1-39. [CrossRef]

3. Kouévi, T.A.; Fatunbi, O.A. Achieving sustainable impact from development projects through multistakeholders innovation platforms: Lessons from Ghana and Rwanda. In Proceedings of the Innovation Conference-Ghana Proceedings, Accra, Ghana, 27-28 September 2016; pp. 123-131.

4. Atikpo, M.; Onokpise, O.; Abazinge, M.; Louime, C.; Dzomeku, M.; Boateng, L.; Awumbilla, B. Sustainable mushroom production in Africa: A case study in Ghana. Afr. J. Biotechnol. 2007, 7, 249-253.

5. Atikpo, M.; Onokpise, O.; Abazinge, A.; Awumbilla, B. Utilizing seafood waste for the production of mushrooms. In Proceedings of the Florida Academy of Sciences, Melbourne, FL, USA, 10-11 March 2006; FAS Abstracts 2006 Meeting. Agric. Sci. (AGR): AGR-10. Florida Academy of Sciences Inc.: Melbourne, FL, USA, 2006.

6. Hafiz, F.; Begum, M.; Parveen, S.; Nessa, Z.; Azad, A.K.M. Study of edible Mushroom grown on Eucalyptus camaldulensis trunk and under soil of Albizzia procera. Pak. J. Nutr. 2003, 2, 279-282.

7. Matila, P.; Salo-Vaananen, P.; Kanko Aro, H.; Jalava, T. Basis Composition and amino acid contents of Mushrooms cultivated in Finland. J. Agric. Food Chem. 2002, 50, 6419-6422. [CrossRef]

8. Lelley, J.I.; Janben, A. Interactions between supplementation, fructification surface and productivity of the substrate of Pleurotus species. In Proceedings of the First International Conference on Mushroom Biology and Products, Hong Kong, China, 23-26 August 1993; Chang, S., Buswell, J.A., Chiu, S., Eds.; 1993; pp. 85-92.

9. Tortoe, C.; Quaye, W.; Akonor, P.T.; Buckman, E.S. Improving Food Security in Africa through Increased System Productivity of Biomass-Based Value Webs; Technical Report, CSIR-FRI/FARA; FARA: Accra, Ghana, 2017.

10. Rogers, E.M. Diffusion of Innovations; Free Press: New York, NY, USA, 1995.

11. Nutley, S.; Davies, H.; Walter, I. Conceptual Synthesis 1: Learning from the Diffusion of Innovations; ESRC UK Centre for Evidence Based Policy and Practise: Swindon, UK; Research Unit for Research Utilization: St Andrews, UK, 2012.

12. Partey, S.I.; Kwaku, M.; Frik, O.B. Perception of Bamboo Leaf as Fodder for Livestock Production in Jeduako in the Dry Semi-Deciduous Zone of Ghana; Technical Report, INBAR/FARA; FARA: Accra, Ghana, 2017.

13. Engler, B.; Schoenherr, S.; Zhong, Z.; Becker, G. Suitability of Bamboo as an Energy Resource: Analysis of Bamboo Combution Values dependent on the Culm's Age. Int. J. For. Eng. 2012, 23, 114-121. [CrossRef]

14. Partey, S.I.; Kwaku, M. Bamboo Leaves as Feed Supplement to Sheep Fed a Basal Diet of Pennisetum purpureum (Hematology and Serum Biochemical Analysis); Technical Report, INBAR/FARA; FARA: Accra, Ghana, 2018.

15. Partey, S.I.; Kwaku, M. Nutritional Potential of Bamboo Leaves for Feeding Goats within the Forest Transition and Savannah Zones of Ghana and the Proximate Composition; Technical Report, INBAR/FARA; FARA: Accra, Ghana, 2018.

16. Raji, A.O.; Asiru, W.B.; Abass, B.; Adefisan, O.O. Production of Bio-Plastics and Bio-Gels from Waste of Cassava, Maize and Banana to Promote Their Biomassweb Values; Technical Report, UI/IITA/FIIRO/FARA; FARA: Accra, Ghana, 2018.

17. Asiru, W.B. Production of Bio-Gel and Bio-Plastic from Agricultural Wastes; Contribution to Online BiomassWeb DGroup Discussion on Demand Driven Research Projects in Africa; FARA: Accra, Ghana, 2018.

18. Adegbite, S.A.; Olukunle, O.J.; Olalusi, A.P.; Adebayo, A.; Asiru, W.B.; Awoyale, W. Mass and Energy Balance Analysis of Pneumatic Dryers for Cassava and Development of Optimization Models to Increase Competiveness in Nigeria; Technical Report, FUTA/IITA/FIIRO/FARA; FARA: Accra, Ghana, 2018.

19. Bamlaku, A.; Loos, T.K.; Habtamu, D.; Saurabh, G. Potential of Bamboo for Employment Creation and Food Security Enhancement in Ethiopia; Technical Report, YIELD/FARA; FARA: Accra, Ghana, 2018.

20. Zenebe, M.; Adefires, W.; Temesgen, Y.; Mehari, A.; Demel, T.; Habtemariam, K. Bamboo Resources in Ethiopia: Their value chain and contribution to livelihoods. Ethno Bot. Res. Appl. 2014, 12, 511-524.

21. International Network for Bamboo and Rattan (INBAR). Study on Utilization of Lowland Bamboo in Benishangul Gumus Region, Ethiopia; INBAR: Beijing, China, 2010. 
22. Kwapong, N.A. Bamboo for land restoration in Ghana. In FAO and INBAR 2018. Bamboo for Land Restoration; INBAR Policy Synthesis Report 4; INBAR: Beijing, China, 2018.

23. FAO; INBAR. Bamboo for Land Restoration; INBAR Policy Synthesis Report 4; INBAR: Beijing, China, 2018.

24. Klerks, L.; Leeuwis, C. Operationalizing Demand Driven Agricultural Research: Institutional Influences in a Public and Private System of Research Planning in the Netherlands. J. Agric. Educ. Ext. 2009, 15, 161-175. [CrossRef]

25. Klerks, L.; Leeuwis, C. Institutionalizing end-user demand steering in Agriculture R \& D: Farmer levy of R \& D in the Netherlands. Res. Policy 2008, 37, 460-472.

(C) 2018 by the authors. Licensee MDPI, Basel, Switzerland. This article is an open access article distributed under the terms and conditions of the Creative Commons Attribution (CC BY) license (http:/ / creativecommons.org/licenses/by/4.0/). 